\title{
The Government's Role in Facing SDGs 2030 Citarum River Clean-up Program, Indonesia: An Analysis
}

\author{
Helen Dian Fridayani \\ Graduate Intitute on Political Economy, Nation Cheng Kung University, Taiwan \\ Corresponding Author: helendianf9@gmail.com
}

\section{Article Info \\ Keyword:}

Citarum River;

Government;

Environmental Issue;

Sustainable

Development;

Kata Kunci:

Sungai Citarum;

Peran Pemerintah;

Masalah Lingkungan;

Pembangunan

Berkelanjutan;

\begin{abstract}
With a watershed area of 690,571, 57 hectares, Citarum is a source of agricultural irrigation water, hydroelectric power, and a source of raw water for drinking water as well as fishing and cultivation land that is utilized by residents in 10 districts and two cities in the province West Java. But Citarum today is faced with acute pollution which results in huge losses to health, economic, social, ecosystem, and environmental resources. This study will discuss how the government deals with SDGs 2030 by cleaning the Citarum River. This study uses a literature review study with the focus of the study on how the government's role in solving the problem of water pollution in the Citarum river, then also focuses on how the government implements Citarum river cleaning programs. Government programs to clean up the Citarum river are considered good, but not yet optimal. Because until now there is still a recalcitrant industry that often dumps waste into the River Basin. Water pollution that occurs in the Citarum River ought to be of sure worry to the Indonesia government, particularly in West Java. By the several programs, neutral policies that protect the environment, and strict supervision it will be useful and works. Not only about the programs and policies that benefit the one-party but also other parties such as the environment and society.
\end{abstract}

Abstrak: Luas DAS 690.571, 57 hektar, Citarum adalah sumber air irigasi pertanian, pembangkit listrik tenaga air, dan sumber air baku untuk air minum serta perikanan dan lahan budidaya yang dimanfaatkan oleh penduduk di 10 kabupaten dan dua kota di provinsi Jawa Barat. Tetapi Citarum saat ini dihadapkan dengan polusi akut yang mengakibatkan kerugian besar pada sumber daya kesehatan, ekonomi, sosial, ekosistem, dan lingkungan. Studi ini akan membahas bagaimana pemerintah menangani SDGs 2030 dengan membersihkan Sungai Citarum. Studi ini menggunakan studi tinjauan pustaka dengan fokus studi tentang bagaimana peran pemerintah dalam menyelesaikan masalah pencemaran air di sungai Citarum, kemudian juga berfokus pada bagaimana pemerintah mengimplementasikan program pembersihan sungai Citarum. Program pemerintah untuk membersihkan sungai Citarum dianggap baik, tetapi belum optimal. Karena sampai sekarang masih ada industri bandel yang sering membuang sampah ke DAS. Polusi air yang terjadi di Sungai Citarum seharusnya mengkhawatirkan pemerintah Indonesia, khususnya di Jawa Barat. Dengan beberapa program, kebijakan netral yang melindungi lingkungan, dan pengawasan ketat itu akan berguna dan berfungsi. Tidak hanya tentang program dan kebijakan yang menguntungkan satu pihak tetapi juga pihak lain seperti lingkungan dan masyarakat.

Article History: Received; 2020-01-25 Revised; 2020-02-04 Accepted; 2020-02-22 


\section{INTRODUCTION}

Citarum River has a very important function and role for life and life in the West Java region. Citarum River is the extensive river in west java which has functions for the surrounding community, particularly for the people around the watershed (Agaton, Setiawan, \& Effendi, 2016). A large portion of them utilize the Citarum stream for everyday use, for instance for drinking and water system (Belinawati, Soesilo, Asteria, \& Harmain, 2018) for the ranchers. The Citarum River is one of Indonesia's vital waterways, from which three multipurpose dams. The hydrological capacity of the Citarum River is to gather precipitation that falls in its watershed (DAS) and to convey it all through its watershed (Quay, 2018). The total surface water runoff of Citarum reaches 16,713.1 million cubic meters per year (Belinawati, Soesilo, Herdiansyah, \& Aini, 2018). Each is divided into runoff in the upstream area of 4,001 million cubic meters, the middle area of 5,259 cubic meters, and 7,453 cubic meters in the downstream area (Terangna Bukit, 2018). The upstream Citarum provides agricultural benefits of Rp.4.2 million/farmer/year so that a total economic value of Rp.1.6 trillion per year is obtained (Quay, 2018). However, the World Bank has named the Citarum River in West Java, as the dirtiest river in the world.

The Citarum River is situated in the western region of Java island, and the bowl covers for around 5,960 km2 (Belinawati, Soesilo, Herdiansyah, et al., 2018). The absolute number of length of the primary waterway is around $315 \mathrm{~km}$ and streams from its water source in wayang mountain to the Java ocean in the north (Terangna Bukit, 2018). The biggest part of the basin is very productive land. More than $56 \%$ of the area is used for agricultural purposes, while the rest includes forests $(27.4 \%)$, industry $(7.9 \%)$, human settlements $(7.4->$ fishponds - $1.3 \%)$ and others using (5.7\%) (Agaton et al., 2016). In the middle basin are three dams, such as Saguling, CICata and Jatiluhur, have been built with a total volume of around $47 \times 108 \mathrm{~m}^{3}$. Citarum watershed overview map displayed.

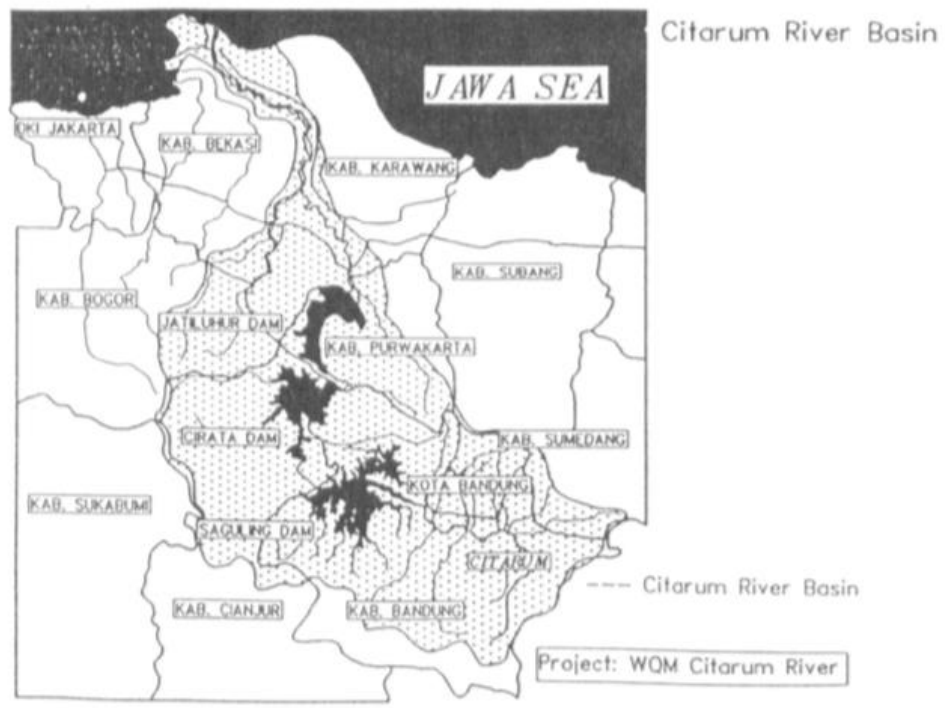

Figure 1

Maps of Citarum River

Source: citarum.org, 2019.

The issue about the Citarum river is related to sustainable development that so-called SDGs. There are a ton of explores about Citarum River that related with to reasonable advancement especially in water and sanitation, just as the neighborhood government mindfulness need to actualize program dependent on SDGs. Of course, the programs launched by the government to clean up the Citarum river are solely to run the SDGs program itself, which has 17 indicators, and one of them is related to provide water and sanitation. Over time, developments along the Ciliwung River increased. The expansion in the populace influenced 
countless settlements and ventures along the Citarum River. Be that as it may, after the development of countless processing plants along the Citarum River, the Citarum River is never again a wellspring of water for inhabitants along basin. No under 3000 plants found upstream are allowed to discard squander into streams or the Citarum River, making the Citarum watershed increasingly dirtied (Hermawan \& Kijima, 2009). Information from the Black Smith Institute and Green Cross Switzerland in 2013 (Napitupulu, L., 2017) shows that Indonesia implies one of the 10 countries that have the most debased conduits on earth and the Citarum River is one of them. Citarum River sullying isn't exactly at one point yet has occurred along the Citarum River from upstream to downstream. The wellspring of the issues that occur in the upper ranges of the Citarum River is overpowered by low open and government thought about nature protection. A couple of issues can be figured as pursues:

1. Shifting of secured regions (woods and non-backwoods) to private, farming and modern territories.

2. The increment in the quantity of zones of debased land because of lack of foresight and observing, contamination of the waterway by local waste, is wastewater from settlements, horticulture, and industry.

3. Groundwater levels that are wild (overexploited) cause subsidence and increment the potential for flood-inclined regions.

Clean and effectively available water for all is a significant part of the world we need to live in and there is sufficient crisp water on this planet to accomplish it. In any case, because of an awful economy or poor infrastructure, a great many individuals including youngsters kick the bucket each year from sicknesses identified with lacking water supply, sanitation and cleanliness. With the pollution of river water in Citarum, another problem that arises is inadequate sanitation. Challenges facing Indonesia related to the problem of drinking water, hygiene and sanitation are still very large. The results of the 2016 Indonesia Sanitation Sector Development Program (ISSDP) study, showed that $47 \%$ of the community still behaved defecate into rivers, rice fields, ponds, gardens and open spaces (Colin, Keetelaar, Utomo, \& Blackett, 2016).

In urban slums including settlements along the Citarum river, poor sanitation is more at risk of causing disease (Maes, Van den Bergh, \& Van den Noortgate, 2019). Poor hygiene culture, population density, and contamination of water by waste, further aggravate the risk of disease. Not only diarrhea, but also other diseases related to cleanliness, such as dysentery, typhus, hepatitis, dengue fever, and scabies. In fact, chronic respiratory diseases can also lurk. This is mostly because the management of solid waste in urban areas is not done well. The agency responsible for these contracts with small private entrepreneurs. The entrepreneurs collect garbage from houses, take it to temporary storage facilities, and then the garbage is transported by the agency. This system often does not work well due to lack of discipline from various parties. From the problems above, this paper will try to discuss related to how the government handles water pollution in the Citarum River through the river cleaning program and also water and sanitation.

\section{A. The Government Role in Political Systems Theory of David Easton}

Political system analysis approach in political science is included in the behavioral approach category. The main idea of the behavioral approach is the emphasis of analysis on human (or community) behavior so that it differs from the institutional approach as its predecessor which emphasizes institutions as units of analysis in the political system (Shirin, Bogolubova, \& Nikolaeva, 2014). Thinking about the political system, could not be separated from other disciplines, especially from astronomy who see events in the universe as part of the solar system or biologists who see events in the human body as part of the human life system (Easton, 1992). Therefore, to facilitate understanding of the political system and how it works, it might be easier if we imagine the human body.

If the human body is part of a system, we will find parts of the system (subsystem) that carry out their respective functions. Eyes to see, ears to hear, and skin to feel. Although every part in the human body is different and performs their respective functions, which of course is 
different too, but that does not mean each of these parts performs its functions as they wish (Evans, 1970). At least there is communication and coordination that allows subsystems in the system to run in tandem without disrupting the other subsystems. Moreover, the loss or malfunction of one of the subsystems can cause overall system paralysis. For example, accidents that cause humans to limp by losing legs on the extreme side can cause death.

According to Easton there are at least three basic things that must be considered in discussing the political system (Easton, 1992). First, the system is characterized by interdependence between units within it. This shows the existence of coherence. Second, the system must be neutral, free from the influence of ideology. Third, the system refers to two things, co-variance and interdependence between units that build the system. Changes in one unit in the system will affect other units in a system. Furthermore, Easton explained that what distinguishes the political system from other systems is in terms of the definition of politics itself. Politics is the struggle of individuals or groups to master social values. Therefore, in the political system there is the principle of allocation of social values (the authoritative allocation of social values). However, differences in the political system with other systems do not necessarily form a gap. A system can be an input for other systems, and vice versa. An example is tax policy. Tax policy is an output of the political system, as well as being an input for the economic system.

There are at least four characteristics of a political system that can distinguish a political system from other systems (Mas'oed, Mohtar, McAndrews, 2008). First, identification characteristics. We must be able to identify the political system to be able to distinguish it from the others. In this identification, there are at least two things that must be considered, namely units in the political system and restrictions. In politics, the units are political actions. As for restrictions, this needs to be considered when we discuss the political system with the environment. Second, input and output. To be able to guarantee the operation of the political system, regular, permanent and steady input is needed. Without input, the political system will not work. Moreover, without output we cannot identify the work that has been generated by the political system. Third, differentiation in the political system. As in the human body, we will not find a unit doing the same thing at the same time.

Members in the political system, at least know the minimum division of labor that provides a structure where the activities take place. In politics, we will find various political actions with their respective roles, for example the legislative, executive, judiciary, political parties, to the interest groups and pressure groups. Fourth, integration in the system. Integration in the political system as an effort to regulate the forces and activities in the political system. Integration in the political system is made possible by the awareness of members of the political system to maintain the existence of the political system itself so that a mechanism that can integrate even forces members to work together even to a minimum so that they can make authoritative decisions.

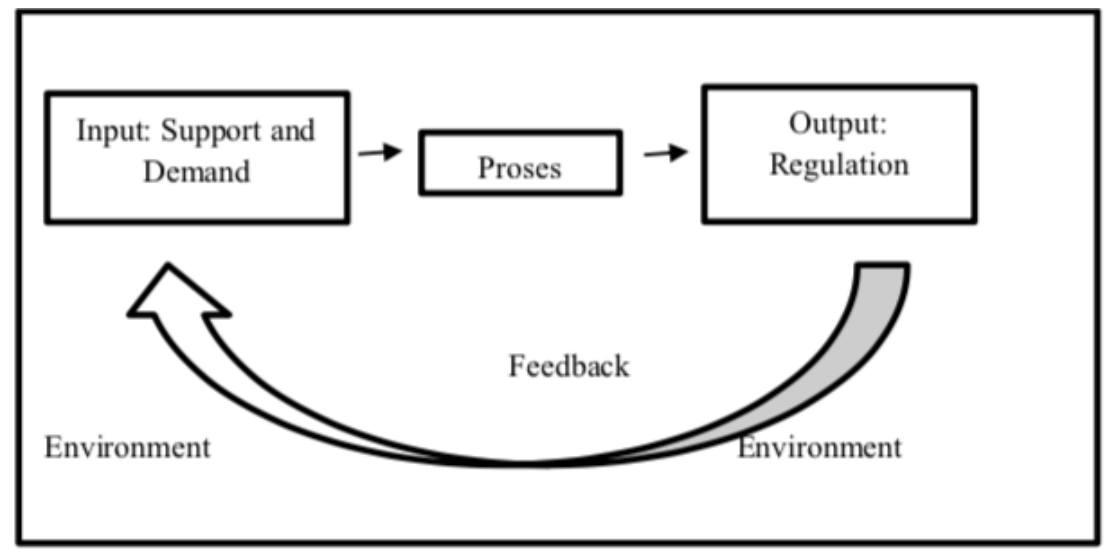

Figure 2

Concept of Political System from David Easton, 1992 


\section{B. Sustainable Development Concept}

Sustainable development is a concept that aims to create a balance between development dimensions, such as economic, social and environmental (Jones, Wynn, Hillier, \& Comfort, 2017). Sustainable development has two main keys, namely, the first is the need for awareness of the needs of the poor in developing countries. Second, the impediments are the restrictions of innovation and social associations identified with ecological ability to address the issues of the present and people in the future. Covering the monetary viewpoints, feasible improvement is firmly identified with financial development and how to discover approaches to propel the economy over the long haul, without exhausting common capital. Be that as it may, the idea of economic development itself is dangerous, on the grounds that the world's own assets are constrained.

Social aspects, which means development with dimensions in humans as far as communication, interrelation and relationship. Which is additionally firmly identified with social perspectives. Not just on financial issues, economical advancement to keep up the social supportability of a general public with the goal that a network can at present exist to live and have for what's to come. Social viewpoints, which implies improvement with measurements in people as far as connection, interrelation and reliance. Which is likewise firmly identified with social perspectives. Not just on monetary issues, supportable improvement to keep up the social maintainability of a general public so a network can at present exist to live and have for what's to come. Reasonable improvement is an uncertain idea, where a wide view falls under its aegis. this idea joins comprehension of feeble manageability, solid supportability, and profound ecology. Different concepts also show a strong trade-off between eco (environment) centrism and anthropology (humans) centrism (Swaminathan \& Kesavan, 2016). Therefore this concept is weakly defined and invites a long debate about its definition.

As a start the emergence of the concept of sustainable development is due to attention to the environment. Particularly characteristic assets that can't be reestablished are being misused persistently (Kates, Parris, \& Leiserowitz, 2015). The idea of not decreasing and yielding the necessities of people in the future is that advancement completed in the here and now ought not harm the earth, be inefficient of regular assets and furthermore focus on people in the future. The cutting edge ought not be excessively ruined by the accessibility all things considered. Be that as it may, they should likewise be allowed the chance to express their innovative plans to develop and create nature and advancement.
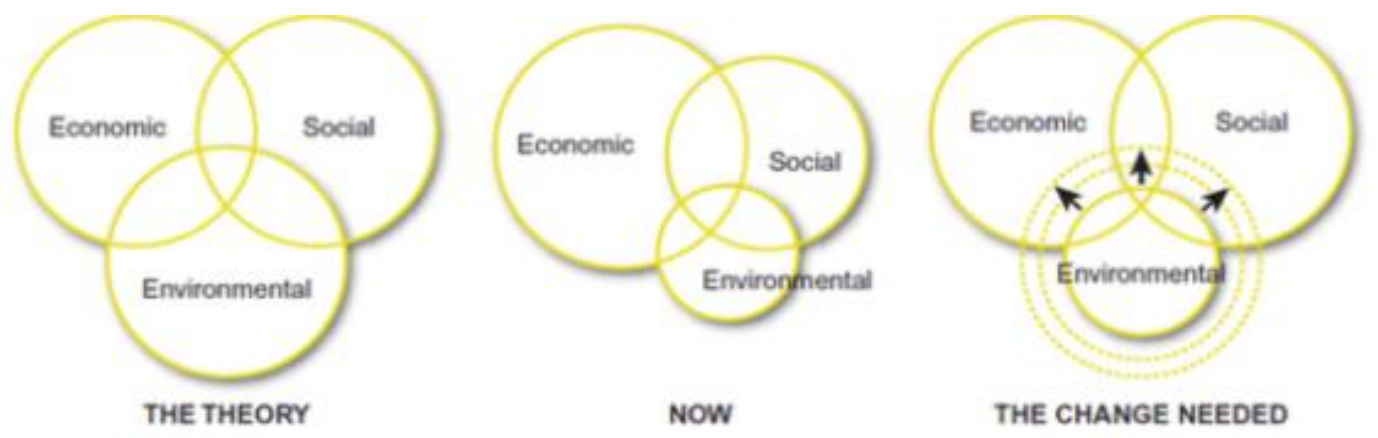

The three pillars of sustainable development, from left to right; the theory, the reality and the change needed to better balance the model

Figure 3

\section{Sustainable Development Plillars, 2015}

Sustainable development is concurred as advancement that addresses current issues without bargaining the privilege to address the issues of people in the future (Klarin, 2018). It contains two significant thoughts: (a) the possibility of "need" which is basic for supporting human life, and (b) the probability of constrainments that originate from the mechanical 
conditions and the normal furthest reaches of social relationship to meet present and future needs.

\section{RESEARCH METHOD}

This research is a qualitative research that is a literature study (library examine) that utilizations books and other writing as the fundamental article (Sugiyono, 2017). Writing study is a movement to assemble data that is important to the theme or issue that is the object of research. Such data can be acquired from books, logical papers, postulations, theses, reference books, the web, and different sources. By conducting a literature study, researchers can utilize all the information and thoughts relevant to their research (Nazir, 2013). The role of library studies before research is very important because by doing this activity the relationship between problems, relevant research and theory will become clearer. In addition, research will be further supported, both by existing theories and by concrete evidence, namely research results, conclusions and suggestions (Nazir, 2013). Literature study contains a systematic description of the study of literature and the results of previous research that has to do with research that will be conducted and endeavored to show the current conditions of the field of science (the state of the art) (Uma, 2006).This type of research is descriptive approach, research that produces information in the form of notes and descriptive data contained in the text under study (Sugiyono, 2017). The reference contains data and information about Citarum river water pollution, government programs and policies, as well as water and sanitation management in Indonesia, especially around the Citarum riverbanks.

\section{RESULT AND DICUSSION}

Citarum River is the longest and greatest conduit in Tatar Pasundan, West Java Province, Indonesia. Citarum waterway streams from its headwaters at Gunung wayang south of the city of Bandung toward the north and discharges into the Java ocean (Belinawati, Soesilo, Herdiansyah, et al., 2018). Citarum flows through 12 district/city administrative areas. Citarum supplies water for the requirements of the vocations of 28 million individuals, the waterway which is a wellspring of drinking water for the individuals in Jakarta, Bekasi, Karawang, Purwakarta, and Bandung. With a length of around $269 \mathrm{~km}$, the water system territory for farming is 420,000 hectares. Citarum is the wellspring of the beat of the Indonesian economy at $20 \%$ of GDP (Gross Domestic Product) with a region of industry situated along the Citarum river (Belinawati, Soesilo, Asteria, et al., 2018). Millions of people depend directly on their lives from this river, around 500 factories stand around the flow, three hydropower dams built in the flow.

The current condition of the Citarum River is very poor. According to information from the Head of the Citarum River Basin, the Citarum River is now classified as the dirtiest river in the world. Based on data on Citarum water quality, from 10 monitoring points the quality of water that falls into the category of hazard or heavily polluted is at four monitoring points Majalaya, Sapan, Cijeruk, and Dayeuhkolot (Hermawan \& Kijima, 2009). One significant parameter passing the threshold is the content of toxic chemicals from the textile industry liquid waste (which has a dyeing, bleaching, and finishing process). In addition to the textile industry waste, the Citarum River is also a waste disposal site for the iron smelting industry, the paper industry and cattle farming. As much as 400 tons of waste is channeled into the Citarum River per day. The Citarum River is the source of life for many as well as one of the centers of state income. How could the river that has given life to many people and also exposure to the country is the dirtiest river in the world? This clearly tarnished Indonesia's reputation. This is due to the waste that flows in Citarum. The waste is very dangerous, it is proven by the large number of fish that die in the Citarum river. Many fish die because they have lived in rivers that have been polluted by industrial waste. Industrial waste is very dangerous because there are many substances that are very dangerous for living things. D

Due to the presence of this dangerous substance also causes water in the Citarum River is no longer clean water and even water that is prohibited for consumption by living things. Clean water is one of the basic human needs, but if the source of clean water is polluted it will cause big problems for human. If humans consume polluted water it will not be a solution to meet 
human needs for clean water but will cause new problems such as diseases caused by polluted water. Therefore the government must act decisively to industries so as not to dispose of their waste carelessly in the Citarum River. The government should have strict regulations and sanctions for violators. The government should immediately conduct the cleanup on the Citarum River so that the river can function as before as a source of life for many people and a source of income for the country. So that the title as the dirtiest river will escape, and the surrounding community can live prosperously.

From 2001 the government has tried to clean up the river starting from upstream to downstream with various program names. The last program that was echoed in 2013, the Citarum Clean, Healthy, Beautiful and Lentari Movement (Bestari) missed the prestigious target. The hope, in 2019, Citarum River water can be drunk. However, until now the quality has not met the water quality standards that have been set, so it is not possible to consume. The recovery of the Citarum River itself already has a roadmap or road map that is contained in strategic interventions per location with short-term (2010-2015), medium-term (2016-2020), and long-term (2021-2025) targets. The Citarum roadmap has identified dozens of projects that are constantly being updated to be implemented. However, related to the achievements of the program so far there has not been a comprehensive study. Beginning in 2018, the Citarum improvement scheme was re-coined. The Citarum Harum Program joins the issuance of Presidential Regulation No. 18 of 2018 concerning the Control of Citarum Watershed Pollution. The Presidential Regulation regulates the scope of duties and authorities of the agencies involved as well as the legal basis for the restoration of the Citarum River. This program is claimed to be more integrated than before with a target of seven years Citarum problems can be resolved divided into three stages namely upstream, middle and downstream.

The first six month period of Citarum Harum is aimed at the socialization as well as law enforcement towards recalcitrant waste-producing industries. The plan, this program will relocate residents of Tarumajaya Village who live on the banks of the headwaters of the Citarum river. The program will also close the vegetable plantation lands in the forest area upstream of the river, and replace them with coffee and wood plants that are soil-strengthening, accompanied by the transfer of professions to the community, especially farmers there.

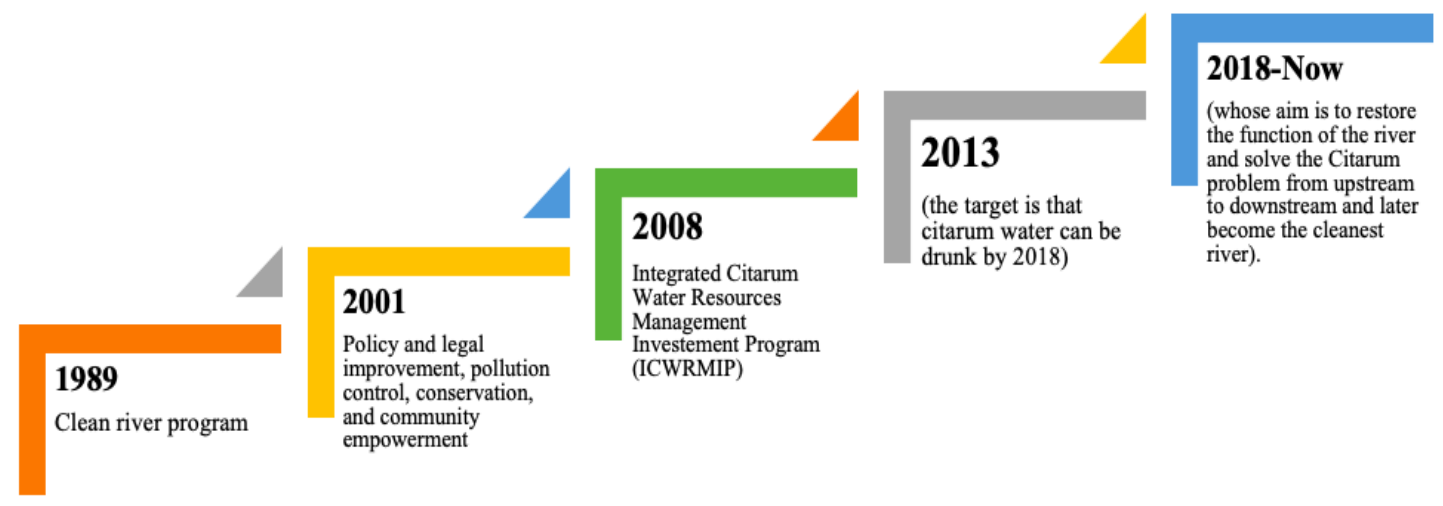

Figure 4

Step years program Citarum River

Source: Author, 2019

Of the many programs run by the Indonesian government, there are several things that must be explained. First seen based on the concept of strength in the form of resources, skills, or other advantages associated with stakeholders. Quality is an exceptional challenge that gives an association an upper hand. The realization of a clean citarum river is based on many supporting factors such as government programs or policies. Support from the government is also from the private sector, both from within and outside the country. Strength analysis is used to analyze various positive supports to support the success of the program. Shortcoming investigation alludes to the impediments or absence of assets, abilities and capacities that viably prevent the 
presentation of an association. These impediments can be as offices, budgetary assets, the executives' abilities and showcasing aptitudes, which makes the wellspring of issues in an association.

Second, sustainable development is a significant challenge for the around the word and as a demonstration of making guidelines to take care of issues, called SDGs. Indonesia, is one of the said countries, needs to achieve its targets, in the Government of West Java (Indonesia) looked with the essential issue being dirtied in the Citarum River. This is of explicit stress to the close by government since West Java is starting at now going up against another goal, which is: SDGs. That is a continuation of the MDGs. During the MDG time frame, the West Java Government had a program to deal with the Citarum River issue, called Citarum Bestari. Regardless, to achieve the SDG targets, the Government of West Java needs another system to decide the issue. Since the past program was made for MDGs, the condition of the Citarum River has not changed a great deal.

Plan making subject to supply and demand, looked by the Government of West Java with SDGs requests. In SDGs the utmost of the Central Government isn't controlled, considering the way that the course of action utilized in the SDGs is the obligation of near to governments to satisfy these destinations. The West Java government has different dares to clean the Citarum River from water debasement which can be found in the diagram above. At present the West Java Government must move the speediest in settling this issue. David Easton's political framework hypothesis sees how governments make game arrangements/rules. Requesting from SDGs, yet moreover from the framework and NGOs, the including framework helped by NGOs engaged the West Java Government to make arrangements in pounding the Citarum River issue. By uprightness of the Citarum River catcher duty from aces is required, from healthy people similarly as from social and money related specialists. The organization needs to look at the course and information gave by aces, with a definitive target of better Citarum.

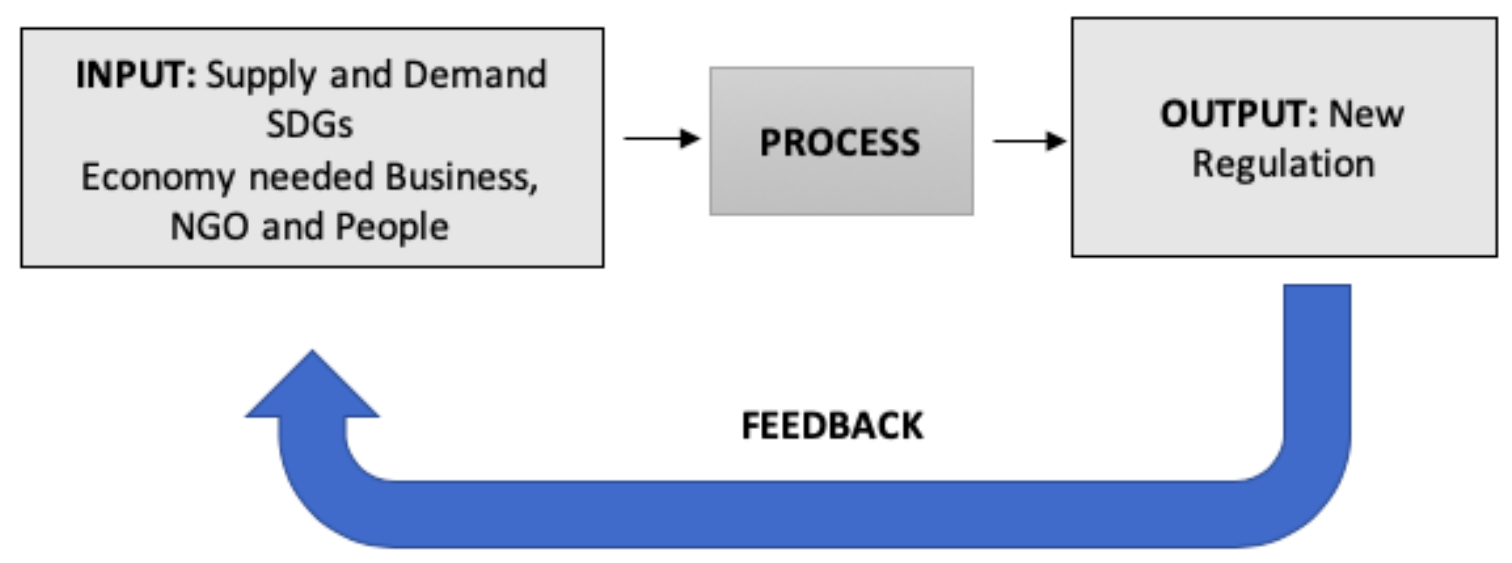

Figure 5

David Easton's Theory Implementation in Citarum Case by Author (2019)

As the mention from many NGO's that concerned with the case, many programs that continue to be carried out by the government, but the most important thing is the government's willingness to implement Law No. 32 of 2009 concerning environmental management in the form of strict actions against factories operating along the Citarum River and have disposed of their waste arbitrarily to river in accordance with Article 76 as follows (1) The Minister, representative, or official/civic chairman applies authoritative assents to the individual accountable for the business and/or movement if under supervision is found to disregard the ecological grant. (2) Administrative approvals comprise of: a. composed admonition; b. government intimidation; c. freezing of ecological grants; or d. denial of ecological grant Article 80 (1) Government compulsion as alluded to in Article 76 passage (2) letter b as: a. brief suspension of generation exercises; b. move of creation offices; c. conclusion of sewerage or 
discharges channels; d. destruction; e. appropriation of merchandise or devices that can possibly cause infringement; f. brief suspension all things considered; or g. different activities planned for halting infringement and activities to reestablish natural capacities. (2) Imposition of government intimidation can be dropped without earlier notice if an infringement has caused: a. an intense danger to people and nature; broad if not quickly ended contamination and/or devastation; and/or c. more noteworthy misfortune to the earth if contamination and/or annihilation isn't promptly ended. The expectation, with the new program called citarum harum by including numerous gatherings to the president, law requirement must be maintained. Projects that spend a great deal of government spending will likewise be pointless for some businesses and individuals who don't know about the transfer of trash into the Citarum River. The guideline as of now exists, however authorization must be amplified.

\section{CONCLUSION}

Citarum river pollution has existed since the 89s. The government program to clean the Citarum River has never stopped from 1989 until now in 2019. Of all the programs that have been carried out, until the policies made by the government, especially West Java, are inseparable from demands and support. In order to meet the goals of the SDGs in 2030 the demand for water and sanitation by the government, the community, NGOs, and businesses around the Citarum River must work together, in accordance with David Easton's theory that input will be processed into output. In this case the government has implemented a program involving many elements. However, the program must be accompanied by government policies or regulations on environmental governance that can have a positive impact on the environment and society. What the government and the community need to do is to uphold the law as fairly as possible.

\section{REFERENCE}

Agaton, M., Setiawan, Y., \& Effendi, H. (2016). Land Use/Land Cover Change Detection in an Urban Watershed: A Case Study of Upper Citarum Watershed, West Java Province, Indonesia. Procedia Environmental Sciences, 33(April), 654-660. https://doi.org/10.1016/j.proenv.2016.03.120

Belinawati, R. A. P., Soesilo, T. E. B., Asteria, D., \& Harmain, R. (2018). Sustainability: Citarum River, government role on the face of SDGs (water and sanitation). E3S Web of Conferences, 52, 1-7. https://doi.org/10.1051/e3sconf/20185200038

Belinawati, R. A. P., Soesilo, T. E. B., Herdiansyah, H., \& Aini, I. N. (2018). BOD Pressure in the sustainability of the Citarum River. E3S Web of Conferences, 52, 1-7. https://doi.org/10.1051/e3sconf/20185200037

Colin, J., Keetelaar, C., Utomo, N. T., \& Blackett, I. (2016). Urban Sanitation in Indonesia: Planning for Progress. (April), 1-24. https://doi.org/10.13140/RG.2.2.31191.88483

Easton, D. (1992). The Political System. New York: Knopf.

Evans, M. (1970). Notes on David Easton's model of the political system 1 . Journal of $\begin{array}{llll}\text { Commonwealth } & \text { Political } & \text { Studies, } & \text { 117-133. }\end{array}$ https://doi.org/10.1080/14662047008447120

Hermawan, P., \& Kijima, K. (2009). Conflict analysis of Citarum River Basin pollution in Indonesia: A drama-theoretic model. Journal of Systems Science and Systems Engineering, 18(1), 16-37. https://doi.org/10.1007/s11518-009-5096-z

Jones, P., Wynn, M., Hillier, D., \& Comfort, D. (2017). The Sustainable Development Goals and Information and Communication Technologies. Indonesian Journal of Sustainability Accounting and Management, 1(1), 1. https://doi.org/10.28992/ijsam.v1i1.22

Kates, R. W., Parris, T. M., \& Leiserowitz, A. A. (2015). What is sustainable development? Goals, indicators, values, and practice. Environment, 47(3), 8-21. https://doi.org/10.1080/00139157.2005.10524444

Klarin, T. (2018). The Concept of Sustainable Development: From its Beginning to the Contemporary Issues. Zagreb International Review of Economics and Business, 21(1), 67-94. https://doi.org/10.2478/zireb-2018-0005 
Maes, P., Van den Bergh, R., \& Van den Noortgate, J. (2019). Water, sanitation, and hygiene. In Oxford Handbook of Humanitarian Medicine. https://doi.org/10.1093/med/9780199565276.003.0056

Mas'oed, Mohtar, McAndrews, C. (2008). Perbandingan Sistem Politik. Yogyakarta: Gadjah Mada University Press.

Napitupulu, L., and G. H. (2017). Downstream Impacts of Water Pollution in the Upper Citarum River, West Java, Indonesia. Economic Assessment of Interventions to Improve Water Quality. Retrieved from https://www.adb.org/sites/default/files/publication/154493/citarumriver-downstream-impacts-water-pollution.pdf

Nazir, M. (2013). Metode Penelitian. Bogor: Ghalia Indonesia.

Quay, C. (2018). Water Quality Impacts of the Citarum River on Jakarta and Surrounding Bandung Basin.

Shirin, S. S., Bogolubova, N. M., \& Nikolaeva, J. V. (2014). Application of David Easton's model of political system to the world wide web Sergey Sergeevich Shirin. World Applied Sciences Journal, 30(8), 1083-1087. https://doi.org/10.5829/idosi.wasj.2014.30.08.14115

Sugiyono. (2017). Metode Penelitian Kuantitatif, Kualitatif dan R\&D. Bandung: PT Alfabet.

Swaminathan, M. S., \& Kesavan, P. C. (2016). Achieving the sustainable development goals. Current Science, 110(2), 127-128. https://doi.org/10.18520/cs/v110/i2/127-128

Terangna Bukit, N. (2018). Water quality conservation for the Citarum River in West Java. Water Science and Technology, 31(9), 1-10. https://doi.org/10.1016/0273-1223(95)00400-H

Uma, S. (2006). Research Methods for Business. Jakarta: Salemba Empat. 